\title{
Seni Tari Tepak Keraton Terhadap Budaya Palembang Darussalam
}

\author{
Syarifuddin, Adhitya Rol Asmi, Nabilah Julaika Putri \\ syarifuddin@fkip.unsri.ac.id \\ Universitas Sriwijaya, Sumatera Selatan
}

\begin{abstract}
The art of the Tepak Keraton dance was originally used in a procession to welcome the arrival of big guests / dignitaries in the land of Palembang. The purpose of this study was to examine the relationship between the Tepak Keraton Dance and the Culture of the Sultanate of Palembang Darussalam. This research was conducted using historical methods consisting of heuristics, source criticism, interpretation, and historiography stages. This study uses an anthropological approach with in-depth interviews with the son of the creator of the Tepak Keraton Dance, Mirzha Indah Dewi. The results showed that the traditional Tepak Keraton dance with Islamic values of Palembang Darussalam raised the majesty and cultural values inherited by the civilization of the Sultanate of Palembang Darussalam. The uniqueness of this dance is in the variety of movements in the form of pencak silat which still inherits the tradition of the Palembang Darussalam Sultanate. Accompanied by the song and poem "Six Brothers". This shows that a palace princess is not only gentle but also skilled and able to protect herself and is authoritative. The variety of dance moves that are very interesting contain the deep meaning of the character of the Palembang Sultanate. So, it becomes very unique in the procession of cultivating this dance art.
\end{abstract}

Keywords:art, tepak keraton, palembang darussalam

\begin{abstract}
Abstrak
Seni Tari Tepak Keraton mulanya dipakai dalam prosesi penyambutan kedatangan tamu besar/ tamu agung di tanah Palembang. Tujuan penelitian ini ialah untuk mengkaji relasi antara Tari Tepak Keraton dengan Budaya Kesultanan Palembang Darussalam. Penelitian ini dilakukan dengan menggunakan metode historis yang terdiri dari tahap heuristik, kritik sumber, interpretasi, dan historiografi. Studi ini menggunakan pendekatan antropologi dengan wawancara yang mendalam dengan anak pencipta Tari Tepak Keraton yaitu Mirzha Indah Dewi. Hasil penelitian menunjukkan bahwa kesenian Tari Tepak Keraton yang khas dengan nilai-nilai Islami Palembang Darussalam yang mengangkat keagungan dan nilai-nilai budaya yang diwariskan oleh peradaban Keraton Keslutanan Palembang Darussalam. Keunikkan tarian ini ada pada ragam gerak berupa pencak silat yang masih mewarisi tradisi dari Kesultanan Palembang Darussalam. Diiringi lagu dan syair "Enam Bersaudara". Hal ini menunjukkan bahwa seorang putri keraton tidak hanya lemah lembut namun juga terampil serta mampu untuk melindungi diri dan berwibawa.Ragam gerak tari yang sangat menarik mengandung makna karakter Kesultanan Palembang yang mendalam. Maka, hal tersebut menjadi sangat unik dalam prosesi penggarapan seni tari ini.
\end{abstract}

Kata Kunci: Kesenian, Tari Tepak Keraton, Palembang Darussalam 


\section{Pendahuluan}

Palembang dalam labirin memori kolektif kebudayaan dimulai dari periode kedatuan Sriwijaya, diteruskan periode penguasaan bajak laut China, periode Kerajaan dan Kesultanan, masa Kolonial serta masa Republik Indonesia (Wolters, 2011). Dari berbagai periode tersebut, periode Kerajaan dan Kesultanan Palembang merupakan periode yang meninggalkan pewarisan penuh bagi masyarakat Palembang, terutama pewarisan seni tari dengan segala nilai-nilai yang dilakoni dalam masyarakat (Utomo, Bambang Budi, 2005).

Saat ini Palembang merupakan salah satu kota yang mengalami perkembangan yang sangat pesat. Dari awalnya hanya dikenal sebagai sebuah kota tua yang usianya terlihat renta. Namun sekarang Palembang menjadi sebuah kota tua yang cantik dan bergaya (Azhari, 2011). Berbicara kota tua tentu tidak tepat bila suatu kota disebut kota tua tanpa adanya tinggalan budaya yang panjang (Yenna, et.al,. 2019). Hal ini bisa berbentuk teknologi klasik, budaya yang melekat pada agama, kesenian tari, kesenian musik, dan sebagainya. Dalam penelitian ini kita akan banyak menelisik tarian khas peninggalan kota tua Palembang.

Tarian pada hakikatnya diciptakan menurut tingkat intelektual, kemampuan dan kreativitas seniman dari pendukungnya dengan mempertimbangkan potensi dan kualitas nilai-nilai tradisonal yang berkembang dan mencerminkan dari waktu ke waktu (Widyastutieningrum, 1997). Tari sambut kota Palembang mempunyai banyak ragam yaitu: (1) Tari Tanggai, (2) Tari Gending Sriwijaya, (3) Tari Tepak Keraton, (4) Tari Tepak, dan (5) Tari Tanggai Perkembangan (Wawancara Mirzha Indah Dewi, 2020a). Tari sambut merupakan tarian kehormatan untuk menyambut tamu. Disajikan dengan gerakan tarian yang lemah gemulai dan memiliki nilai keagungan (Syarofie, 2019).

Istilah keraton, yang terbayang oleh pembaca dan pendengar kata tersebut yaitu berupa sebuah lingkungan tempat tinggal Sultan (Sustianingsih, et.al. 2019). Sesuai dengan tempat berkembangnya tari tersebut, tentu masyarakat awam akan mengira bahwa kesenian Tari Tepak Keraton berasal dari kesenian tari yang berkembang di Keraton Kesultanan Palembang Darussalam. Namun, pada faktanya kesenian Tari Tepak Keraton lahir dan berkembang jauh setelah Kesultanan Palembang Darussalam dibubarkan pemerintah Hindia-Belanda. Kesenian tari ini diciptakan secara ketidak sengajaan oleh Anna Kumari selaku ketua tim kesenian yang di asuh oleh Inmidam IV/SWJ/Induk Administrasi IV/SWJ yang pada saat itu ia ditugaskan oleh Kolonel Makmun Rasyid. 
Ketika Tari Sambut yang ada di Palembang tidak bisa ditampilkan, maka lahirlah seni tari baru yaitu tari Tepak Keraton yang di buat oleh Anna Kumari. Pada tahun 1967dalam rangka kedatangan Panglima Kodam IV Brigjen Ishak Juarsa yang menjabat sejak 17 Juni 1967 hingga 7 Februari 1970 sebagai Panglima Kodam Sriwijaya.

Lalu, pihak Kodam IV Sriwijaya menugaskan Kolonel Makmun Rasyid dalam mencari sebuah tarian yang cocok untuk prosesi penyambutan. Setelah itu Kolonel Makmun Rasyid meminta Anna Kumari yang bertanggung jawab sebagai ketua tim kesenian di bawah binaan Inmindam IV/SWJ/Induk Administrasi IV/SWJ. Tim kesenian ini beranggotakan 30 orang yang terdiri berupa penari berasal dari Persatuan Anak Priayi Palembang (PAPPA), sedangkan yang menjadi peraga pencak silat berasal dari Pencak Keraton Palembang Asli (PKPA), penyanyi dan pemusik (Wawancara Vebri Al-Lintani, 2020).

Setelah semua panitia dipersiapkan, Anna Kumari selaku penggarap utama merancang tari sambut tersebut. Sosok Anna Kumari telah banyak mengenal budaya Palembang sehingga dalam perancangan beliau tidak banyak mengalami kesulitan dalam memasukkan nilai-nilai budaya Kesultanan Palembang (Wawancara Mirzha Indah Dewi, 2020b).

Mengenai lagu yang dipakai ia merasa cocok dengan lagu Melayu yang berjudul "Enam Saudara". Setelah itu Anna Kumari segera membuatkan syair yang isinya sesuai dengan nuansa Kesultanan Palembang Darussalam, mengenai siapa pengarang asli lagu "Enam Bersaudara" tersebut tidak diketahui secara pasti. Lagu dan syair "Enam Bersaudara memiliki arti makna kebahagian, kerukunan, serta keramahan yang diwariskan pada Kesultanan Palembang Darussalam (Lintani, 2016).

Dengan mudahnya sosok Anna Kumari membuat ragam gerak pada Tari Tepak Keraton. Pada waktu beberapa hari saja ia dapat selesai menggarap satu tarian.Pada awal mulanya, para penari menggunakan busana Aesan Gede dan Aesan Sala Mantri/Selendang Mantri yang bercorak kerajaan Sriwijaya. Tetapi, setelah diteliti lebih lanjut mengenai sejarah Kesultanan Palembang Darussalam busana yang dikenakan dalam tari Tepak Keraton diubah menjadi Aesan Pak Sangkong yang sesuai dengan budaya Islam pada Kesultanan Palembang Darussalam.

Tari Tepak Keraton merupakan tarian yang unik dan berbeda dengan tari sambut lainnya yang berada di Sumatera Selatan. “...Semua penari tari Tepak Keraton ialah wanita, bahkan yang membawa payung serta tombak pada tari tersebut ialah wanita yang masih keturunan Keraton. Tarian ini 
memiliki seni gerak tarian yang unik pada ragam pencak silat yang masih mewarisi tradisi dari Kesultanan Palembang Darussalam. Hal ini menunjukkan bahwa seorang putri keraton tidak hanya gemulai, lembut namun juga terampil serta mampu untuk melindungi diri dan berwibawa (Wawancara Mirzha Indah Dewi, 2020b).

Peneliti tertarik dalam penulisan ini karena kesenian Tari Tepak Keraton yang khas dengan nilai-nilai Islami pada masa Kesultanan Palembang Darussalam yang menggambarkan semua penari ialah wanita yang memiliki garis keturunan keraton, serta menggambarkan persaudaraan yang sangat erat terdapat pada lagu dan syair tari Tepak Keraton. Hal tersebut menjadi sangat unik dalam prosesi penggarapan seni tari ini.

Sebelumnya sudah ada yang melakukan penelitian mengenai tari sambut di beberapa daerah dan di Indonesia seperti: Makna Gerak Tari Tanggai di Kota Palembang Sumatera Selatan artikel yang dibuat oleh Gabriella Saras Katungga, Tari Gending Sriwijaya: Moralitas dalam Refleksi Historis Civil Society artikel yang dibuat oleh Yoan Mareta,dkk, dan Tesis yang dibuat oleh Maulidiwati dengan judul Simbol dan Makna Tari Tepak Keraton di Palembang Sumatera Selatan. Namun, penelitian mengenai tari sambut Tepak Keraton terhadap budaya Palembang Darussalam belum ada yang melakukan penelitian terhadap nilai budaya yang terkandung dalam seni tari Tepak Keraton.

Berdasarkan hal di atas maka peneliti mengangkat judul "Seni Tari Tepak Keraton Terhadap Budaya Palembang Darussalam" dengan tujuan menjaga tradisi seni tari yang ada di Kota Palembang. Rumusan masalah yaitu: (1). Bagaimana ciri khas seni Tari Tepak Keraton, (2). Syair dan musik Tari Tepak Keraton, dan (3). Ragam gerak Tari Tepak Keraton.

Penelitian terdahulu yang terkait dengan penelitian ini ialah berjudul Tari Tepak Keraton yang ditulis oleh Vebry Al Lintani, dan thesis dengan judul Simbol dan Makna Tari Tepak Keraton Di Palembang Sumatera Selatan yang ditulis oleh Maulidiawati. Kedua penelitian tersebut fokus pada penelitian nilai budaya dan pemaknaan gerak tari, sedangkan penelitian ini ialah penelitian historis dengan pendekatan-pendekatan budaya. Berdasarkan uraian diatas peneliti tertarik untuk mengadakan penelitian dengan judul "Seni Tari Tepak Keraton Terhadap Budaya Palembang Darussalam". 


\section{Metode Penelitian}

Penelitian ini menggunakan metode sejarah, yang dibagi atas empat prosedur kegiatan yaitu: Heuristik, Kritik (verifikasi), Interpretasi, dan Historiografi (Daliman, 2018). Heuristik ialah tahap pengumpulan sumbersumber (Sair, 2012). Adapun beberapa sumber yang menjadi acuan dalam penulisan ini diantaranya sebagai berikut: Tulisan dari Surti Jiwanti dan Chaya I Nyoman: Bentuk Tari Tepak Keraton di Kota Palembang Provinsi Sumatera Selatan (2016), Vebry Al Lintani : Tari Tepak Keraton. Deepublish: Yogyakarta (2016), dan Maulidiawati : Simbol dan Makna Tari Tepak Keraton Di Palembang Sumatera Selatan. Thesis Program Pascasarjana Universitas Pendidikan Indonesia (2018).

Setelah ditemukannya sumber-sumber penelitian sejarah, maka yang dilakukan adalah uji validasi sumber yang dalam penelitian sejarah lebih dikenal sebagai kritik (verifikasi) sumber-sumber sejarah (Hamidah, 2013). Dalam penelitian ini ada dua kritik sumber yang digunakan yakni kritik ekstern dan kritik intern (Irwanto, 2014).

Buku dengan judul Tari Tepak Keraton yang ditulis oleh Vebry Al Lintani, dan thesis yang berjudul Simbol dan Makna Tari Tepak Keraton Di Palembang Sumatera Selatan yang ditulis oleh Maulidiawati. Kedua penelitian ini cukup menarik dalam mengkaji Tari Tepak Keraton seperti Vebry Al Lintani ialah tokoh budayawan Sumsel dan Maulidiawati yang menyelesaikan keilmiahan penelitian ini dalam bentuk thesis, tentu keduanya memiliki nilai masing-masing.

Langkah selanjutnya ialah melakukan interpretasi, peristiwa sejarah yang diinterpretasikan dalam tahap ini ialah menghubungkan fakta atau data antara sumber yang satu dengan sumber yang lainnya (Sjamsudin, 2007). sehingga muncul suatu pemahaman yang utuh terhadap seni Tari Tepak Keraton. Peneliti menginterpretasikan hasil data sejarah yang telah dikumpulkan baik melalui sumber-sumber tulisan ilmiah dan sumber wawancara kepada Mirzha Indah Dewi atau Iin Kumari yang merupakan anak dari pencipta Tari Tepak Keraton. Serta menginterpretasikan hasil wawancara dengan Vebry Al Lintani yang merupakan tokoh budayawan Sumsel.

Langkah terakhir ialah historigrafi atau penulisan sejarah untuk merentruksi suatu gambaran masa lampau berdasarkan data yang diperoleh (Kuntowijoyo, 1995). Historiografi dalam penelitian ini yang berupa tulisan seni Tari Tepak Keraton terhadap budaya Palembang Darussalam dengan memaknai ciri khas seni Tari Tepak Keraton, syair dan musik Tari Tepak Keraton, serta ragam dan gerak Tari Tepak Keraton. 


\section{Hasil dan Pembahasan Penelitian}

\section{Ciri Khas Seni Tari Tepak Keraton}

Peristiwa besar berdarah pada tahun 1965 yang terkenal dengan istilah Gerakan 30 September yang dilakukan oleh Partai Komunis Indonesia (PKI) menjadikan kondisi sosial masyarakat Indonesia mencekam (Soedarmo \& Ginanjar, 2014). Hal-hal yang terdapat unsur PKI dan komunisme akan dengan cepat dihapuskan keberadaanya. Tindakan ini dilakukan oleh pihak rezim Orde Baru dalam menghilangkan pengaruh ajaran komunisme secara total (Sanita dan Rianto, 2018). Situasi tersebut memengaruhi kondisi sosial budaya masyarakat termasuk di kota Palembang. Tari sambut Gending Sriwijaya yang diciptakan di masa pemerintahan Jepang ini dilarang digelar di hadapan khalayak ramai. Hal tersebut dikarenakan pengarang syair tari Gending Sriwijaya Nungcik AR, ialah salah seorang pengurus Partai Komunis Indonesia. Padahal, bila kita melihat isi daripada syair tersebut tidak terdapat unsur komunisme yang dibawa oleh Partai komunis Indonesia. Isi syair tersebut secara penuh menaikkan eksistensi sejarah dan kebesaran budaya yang ada pada masa kerajaan Sriwijaya.

Budaya merupakan organisai sosial dari suatu kelompok negara tertentu yang meliputi, kepercayaan, seni, cara hidup (Hornby, 2010). Seiring berjalannya waktu budaya Palembang Darussalam memiliki perkembangan yang sangat pesat dan memiliki akulturasi budaya yang unik dengan nuansa eksotis. Kebudayaan Melayu dan Jawa melarut menjadi satu dalam perkembangan di Palembang, digodok oleh local genius dan disebutlah sebagai kebudayaan Palembang (Hanafiah, 1995). Pengaruh budaya Palembang sudah terlihat sejak abad 19 (Peeters, 1997).

Kota Palembang pada masa lampau dengan sejarah gemilangnya memiliki banyak warisan budaya yang bernilai dan mempunyai arti tinggi (Kumari \& Dewi, 2013). Palembang mempunyai banyak nilai kearifan lokal yang luar biasa terutama dari peninggalan seni tari (Lintani, 2016). Djohan Hanafiah budayawan Palembang masa lalu mengungkapkan "Palembang" merupakan kosa kata dari kata lembang yang berarti tanah yang rendah, serta akar yang membengkak karena lama terendam di air (Ikhsan, 2018).

Tari Tepak Keraton merupakan tari yang mengangkat keagungan dan nilai-nilai budaya yang diwariskan oleh peradaban Keraton Kesultanan Palembang Darussalam (Lintani, 2016). Tari Tepak Keraton merupakan tarian adat kota Palembang yang dibuat khusus untuk menyambut kedatangan tamu besar/ tamu agung yang masih dipakai hingga saat ini di acara penyambutan tamu, resepsi pernikahan, dan acara resmi (Balitbangnovda, 2013). 
Dalam menyambut tamu kehormatan, tarian merupakan tradisi di Palembang. Seni tari yang diwarisi oleh masyarakat Palembang tempo dulu menjadi daya tarik bagi para tamu yang berasal dari luar Kota Palembang (Hera, 2020).

Tari Tepak Keraton menjadi salah satu jenis tarian yang terus dijaga keberadaannya selain Tari Gending Sriwijaya dan Tari Tanggi. Tari Tepak Keraton lebih bernuansa islami yang menunjukkan kebesaran Kesultanan Palembang Darussalam. Keunikannya terletak pada nilai-nilai beladiri yang ada pada garapan geraknya. Sedangkan, Tari Gending Sriwijaya cenderung menampakkan kesan Budhisme yang ada pada Kerajaan Sriwijaya (Jiwanti \& Chaya, 2016).

Tari Tepak Keraton merupakan tari yang mengangkat keagungan dan nilai-nilai budaya yang diwariskan oleh peradaban Keraton Kesultanan Palembang Darussalam (Lintani, 2016). Tari Tepak Keraton merupakan tarian adat kota Palembang yang dibuat khusus untuk menyambut kedatangan tamu besar/ tamu agung yang masih dipakai hingga saat ini di acara penyambutan tamu, resepsi pernikahan, dan acara resmi (Balitbangnovda, 2013).

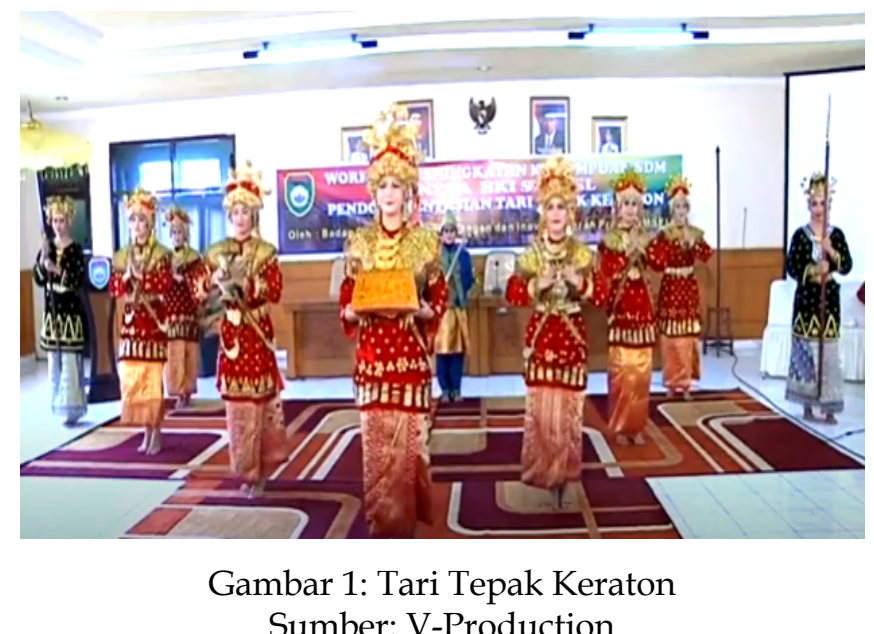

Tari Tepak Keraton diciptakan oleh Anna Kumari pada saat penyambutan Brigjen Ishak Juarsa selaku Panglima Kodam IV Sriwijaya. Tari Tepak Keraton dibawakan oleh 7 orang penari; (1). Penari pertama (primadona/membawa tepak), (2). Dua penari berikutnya membawa pridon, (3). Empat penari lainnya memakai tanggai saja, (4). Pembawa payung kembar 1 orang, (5). Pembawa tombak berambut 1 orang, (6). Pemain pencak keraton satu orang (Lintani, 2016). 
Ciri khas dari Tepak Keraton terlihat dari unsur geraknya yang memakai tari Pencak Silat Keraton warisan tradisi budaya dari Kesultanan Palembang Darussalam yang menggambarkan seorang putri keraton tidak hanya kharismatik, lembut, dan cantik namun juga terampil dalam melindungi diri (Wawancara Mirzha Indah Dewi, 2020b).

Para pendukung tari Tepak Keraton terdiri dari perempuan semua, termasuk pembawa payung, pembawa tombak, dan juga pesilat. Hal ini sesuai dengan norma adat Palembang Darussalam yang berdasarkan ajaran Islam bahwa laki-laki tidak diperbolehkan berdekatan dengan perempuan yang bukan muhrim (Lintani, 2016).

\section{Syair dan Musik Tari Tepak Keraton}

Dalam penyajian tari menggunakan musik pengiring karena antara musik dan tari sangat berhubungan (Khutniah \& Iryanti, 2012). Dalam artian musik bukan sebagai abdi tari. Musik seharusnya mendukung kemantapan sehingga dalam pertujunkkan tari musik akan memberikan sentuhan emosional (Jiwanti \& Chaya, 2016).

Lagu dan Syair tari Tepak Keraton "Enam Bersaudara" yang berarti kemakmuran bersaudara, kebahagiaan dan keramahan tuan rumah terhadap tamu yang datang. Syair tersebut berbunyi; "Selamat datang tamu tercinta di Palembang Darussalam, Selamat tiba kami ucapkan kepada tuan".

Dalam syair lagu ini bukan hanya mengucapkan selamat datang, tetapi juga mengucapkan selamat jalan untuk tamu yang akan pulang dan mendoakan kepada Allah Subhanahu Wa Ta'ala sehingga tamu yang akan pulang selmat dalam perjalanan. Pesan ini tersirat pada syair berikut; "Selamat jalan padaku tuan kami kan doakan semoga selamat sejahtera sampai negeri tujuan".

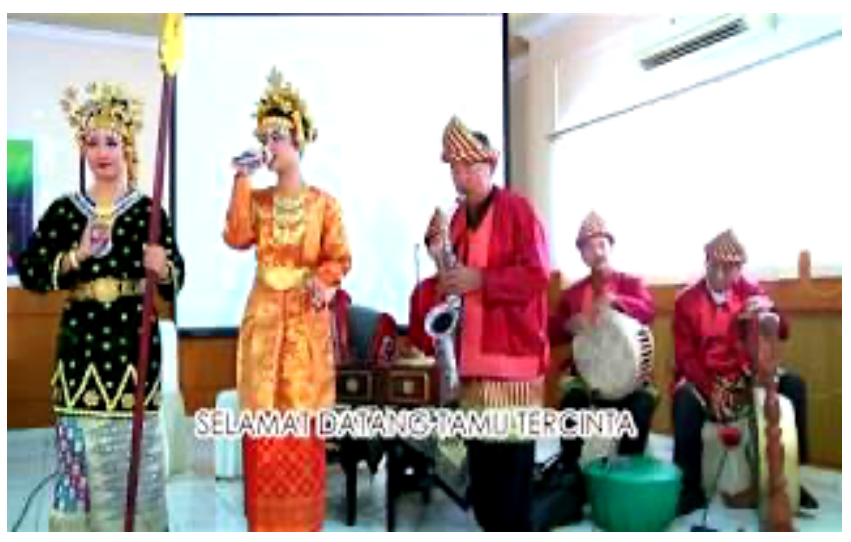

Gambar 2: Alat Musik Pengiring Tari Tepak Keraton Sumber: V-Production 
Tari Tepak Keraton diiriingi dengan alat musik biola, gong, akordion, saksopone, ketipung, gendang melayu, ning nong, dan seruling. Busana yang digunakan tari Tepak Keraton sesuai dengan situasi dan kondisi, misalnya pada saatnya acara pernikahan tari Tepak Keraton menggunakan busana Aesan Paksangkon yang digunakan penari (Bangsawan, 2018)F.

Para pendukung tari Tepak Keraton terdiri dari perempuan semua, termasuk pembawa payung, pembawa tombak, dan juga pesilat. Hal ini sesuai dengan norma adat Palembang Darussalam yang berdasarkan ajaran Islam bahwa laki-laki tidak diperbolehkan berdekatan dengan perempuan yang bukan muhrim (Lintani, 2016).

\section{Ragam Gerak Tari Tepak Keraton}

Sebuah karya seni pada dasarnya mempunyai peranan penting dalam kehidupan manusia. Seni tari mampu membawa manusia ke dalam pemahaman mengenai nilai kebudayaan melalui ragam gerak dalam satu rangkaian tari secara utuh (Tyas, 2018). Penggarapan gerak pada seni tari Tepak Keraton dibuat dengan mudah oleh Anna Kumari, yang meliputi: (1) Jalan Putri: Posisi kaki berjalan sambil kaki disilang menuju panggung, kedua tangan Borobudur. Jalan Jinjit: Posisi kaki jinjit lari kecil menuju panggung selanjutnya berganti posisi, (2) Borobudur hormat: Silang posisi tangan Borobudur, kemudian dilanjutkan tangan sembah hormat, (3) Nyaturi maju: silang kaki maju 3 langklah, kedua tangan kuncup mawar buka depan, kuncup tuutp kanan, kuncup mawar buka kiri, kemudian kembali kuncup mawar kanan. Nyaturi Mundur: Silang kaki mundur 3 langkah, kedua tangan kuncup mawar buka depan, kuncup tutup kanan, kuncup mawar buka kiri, kemudian kembali kuncup mawar kanan, (4) Berperi kanan dan berperi kiri: Silang, posisi badan nyamping kanan, kaki kanan jinjit ke belakang tangan kiri kuncup mawar atas, telinga, tangan kanan kuncup samping pinggang, tangan kiri di ayun ke atas, diputar, kepala digerakkan setengah lingkaran, kemudian pinggang, tangan kiri diayun ke atas, diputar, kepala tangan diayun, (5) Rebah Kayu: Silang, tangan kuncup mawar buka tutup samping kiri badan diputar perlahan sambil berdiri, (6) Duduk tegak jengku: Silang. Berdiri di atas lutut, tangan posisi Borobudur, (7) Nago Besaung: Silang, posisi kedua tangan kuncup mawar berhadapan berdiri sejajar, (8) Tangkis duduk: Silang, gerak silat tangkis tangan, (9) Sembah Hormat: Semua penari gerak hormat, (10) Pencak silat keraton: Pesilat Puteri memperagakan gerak silat keraton menggunakan tombak atau pedang, (11) Kembang dadar duduk selimpuh kanan dan kembang dadar duduk selimpuh kiri: Silang, posisi tangan kiri kuncup mawar buka di atas telinga, tangan kiri kuncup mawar samping pinggang, tangan kiri 
diayun keatas, diputar, kepala tangan diayun, (12) Gunung mahameru duduk kanan dan gunung mahameru duduk kiri: Silang, posisi tangan kiri kuncup mawar buka diatas kepala, tangan kanan, kuncup mawar buka diarahkan dibawah lengan, kedua tangan diputar kearah kiri kemudian diputar balik.

\section{Simpulan}

Tari Tepak Keraton diciptakan secara mendadak oleh Anna Kumari selaku ketua tim kesenian yang di asuh oleh Inmidam IV/SWJ/Induk Administrasi IV/SWJ yang pada saat itu ia ditugaskan oleh Kolonel Makmun Rasyid. Tarian ini menggambarkan nilai-nilai budaya Islami serta keagungan yang diwariskan pada masa Keraton Palembang Darussalam. Keunikannya terletak pada nilai-nilai beladiri yang ada pada garapan geraknya. Lagu dan Syair tari Tepak Keraton "Enam Bersaudara" yang berarti kemakmuran bersaudara, kebahagiaan dan keramahan tuan rumah terhadap tamu yang datang. Ragam gerak tari yang sangat lemah gemulai sekaligus mengandung kekuatan yang menceritakan kekuatan Palembang karakter Palembang Darussalam.

Tari Tepak Keraton merupakan tarian yang unik dan membawa makna Islami, sehingga tarian tersebut masih digunakan hingga saat ini seperti pada acara penyambutan tamu agung dan acara kegiatan Islami seperti MTQ. Berbeda dengan Tari Gending Sriwijaya yang lebih terkesan nilai-nilai Buddhisme khas Sriwijaya.

\section{Daftar Rujukan}

Azhari, R. dan. (2011). Sejarah Kota Palembang. Dinas Kebudayaan dan Pariwisata Pemerintah Kota Palembang.

Balitbangnovda. (2013). Tari Tepak Keraton.

Bangsawan, I. P. R. (2018). Kamus Istilah Tarian Melayu. Dinas Pendidikan Pemuda Olahraga dan Pariwisata Kabupaten Banyuasin.

Daliman. (2018). Metode Penelitian Sejarah. Ombak.

Dewi, K. dan. (2013). Tradisi Palembang Yang Hampir Punah "Rebu Kasan." Kementrian Pendidikan dan Kebudayaan Direktorat Jenderal Kebudayaan Direktorat Sejarah dan Nilai Budaya Rumah Nusantara Dayang Merindu.

Hamidah. (2013). Metodelogi dan Historiografi Sejarah. Palembang: Perpustakaan Nasional Katalog dalam Terbitan (KDT).

Hanafiah, D. (1995). Melayu Jawa: Citra Budaya \& Sejarah Palebang. PT. RAJA 
Grafindo Persada.

Hera, Treny. (2020). Fungsi Tari Tanggai di Palembang. Geter: Jurnal Seni Drama Tari dan Musik, 3(1).

Hornby, A. S. (2010). Oxford Advanced Learners's Dictionary. Oxford University Press.

Ikhsan, R. M. (2018). Palembang Dari Waktoe ke Waktoe. Unsri Press.

Irwanto, dan S. (2014). Metode Penelitian Sejarah. Ombak.

Jiwanti, S., \& Chaya, I. N. (2016). BENTUK TARI TEPAK KERATON DI KOTA PALEMBANG PROVINSI SUMATERA SELATAN. Gelar: Jurnal Seni Budaya, 14(1).

Khutniah, N., \& Iryanti, V. E. (2012). Upaya Mempertahankan Eksistensi Tari Kridha Jati di Sanggar Hayu Budaya Kelurahan Pengkol Jepara. UNNES: Jurnal Seni Tari, 1(1).

Kuntowijoyo, D. R. (1995). Pengantar ilmu sejarah. Bentang Pustaka.

Lintani, V. Al. (2016). Tari Tepak Keraton. Deepublish.

Maulidiawati. (2018). Simbol dan Makna Tari Tepak Keraton di Palembang. Universitas Pendidikan Indonesia.

Peeters, J. (1997). Kaum Tuo Kaum Mudo Perubahan Religius di Palembang 18211942. INNIS.

Sair, Alian. (2012). Metodelogi Sejarah dan Implementasi dalam Peneletian. Criksetra: Jurnal Pendidikan dan Kajian Sejarah.

Sanita, M. \& Rianto, P. (2018). Hantu PKI dan Ujung Rekonsiliasi. Jurnal Komunakasi, 12(2).

Sjamsudin, Helius. (2007). Metodelogi Sejarah. Yogyakarta: Ombak.

Soedarmo, R. \& Ginanjar. (2014). Perkembangan Politik Partai Komunis Indonesia 1948-1965. Jurnal Artefak, 2(1).

Sustianingsih, I.M., et.al. (2019). Peran Sultan Mahmud Badaruddin I dalam Pembangunan Infrastruktur di Kota Palembang 1724-1758. Tamaddun: Jurnal Kebudayaan dan Sastra Islam.

Syarofie, Y. (2019). Tari Tradisi di Sumatera Selatan Oku, Pagaralam, dan Banyuasin. Dinas Kebudayaan dan Pariwisata Sumatera Selatan.

Tyas, G. P. (2018). Nilai Pendidikan Karakter Dalam Ragam Gerak Tari Srimpi Pandelori. Mudra Jurnal Seni Budaya, 33(2), 182-190.

Utomo, Bambang Budi, D. (2005). Perkembangan Kota Palembang Dari Wanua Sriwijaya Menuju Palembang Modern. Pemerintah Daerah Kota Palembang 
Dinas Pariwisata Dan Kebudayaan.

Wawancara Mirzha Indah Dewi. (2020a). Wawancara Mirzha Indah Dewi, 26 September 2020.

Wawancara Mirzha Indah Dewi. (2020b). Wawancara Mirzha Indah Dewi 27 November 2020.

Wawancara Vebri Al-Lintani. (2020). 28 September 2020.

Widyastutieningrum, Sri Rochana. (1997). Pendidikan Tari di Lembaga Formal Tinjauan Mengenai Pembentukan Penari. STSI Press Surakarta.

Wolters, O.W. (2011). Kemaharajaan Maritim Sriwijaya \& Perniagaan Dunia : Abad III-Abad VII. Depok: Komunitas Bambu.

Yenna, Eva et.al. (2019). Kota Tua Palembang dalam Kenangan. Kementrian Pendidikan dan Kebudayaan Direktorat Jenderal Kebudayaan Direktorat Sejarah. 